\title{
Pulmonary support using venovenous bypass and a biological oxygenator ${ }^{1}$
}

\author{
G. L. HAMMOND and H. POULAIN \\ Department of Surgery and Surgical Cardiovascular Research Laboratory, Yale Medical School
}

\begin{abstract}
Hammond, G. L., and Poulain, H. (1974). Thorax 29, 121-124. Pulmonary support using venovenous bypass and a biological oxgenator. A method of providing long-term pulmonary support without the use of an artificial oxygenator or systemic heparinization was investigated.

Three groups of experiments were performed. Group I determined the bypass flow and blood oxygenator requirements of apnoeic animals supported by venovenous bypass. Group II and III experiments evaluated two different methods of oxygenating apnoeic test animals from adjacent parabiotic support animals.

It was determined that a venovenous bypass ratio equal to cardiac output and a $\mathrm{PO}_{2}$ of venous return blood of $150 \mathrm{mmHg}$ was required to maintain satisfactory blood gases. These parameters were provided by support animals and sustained total respiratory support of the test animals for $\mathbf{4 8}$ hours.
\end{abstract}

Long-term pulmonary support for the treatment of potentially fatal but reversible lung disease is a necessary requirement for the management of many critically ill patients. At the present time, most obstacles to prolonged respiratory support are those associated with currently available manufactured oxygenators, that is, the necessity for and dangers of systemic heparinization (White et al., 1971), blood trauma, and material compatibility. In an attempt to overcome some of these problems, experiments were designed to evaluate the ability of a biological oxygenator to provide respiratory support for the apnoeic experimental animal.

\section{MATERIALS AND METHODS}

Three groups of animals were studied. The first group, consisting of one animal in each experiment, determined the oxygen requirements of an apnoeic animal undergoing venovenous bypass. The two remaining groups, consisting of two animals (test and support) in each experiment, evaluated different methods of providing pulmonary support with venovenous bypass.

In group I, the chests of three heparinized, anaesthetized dogs were opened through a median sternotomy and a No. 40 USCI cannula was inserted in the

1Supported by the Hartford Foundation, grant no. 9242-41-55737

Requests for reprints: G. L. Hammond, M.D., Department of Surgery, Yale Medical School, 333 Cedar Street, New Haven, Connecticut 06511, USA right atrium. Venous blood was diverted to a Bentley oxygenator and was then pumped back into either the external jugular or femoral veins. Cardiac output was recorded by an electromagnetic flow probe placed around the ascending aorta. Respirations were paralysed with gallamine, $0.5 \mathrm{mg} / \mathrm{kg}$, and the endotracheal tube was clamped. The rate of venovenous bypass and $\mathrm{PO}_{2}$ of blood in the oxygenator were varied until a satisfactory arterial $\mathrm{PO}_{2}$ of the test animal was achieved. Bypass was from 30 to $150 \%$ of cardiac output and $\mathrm{PO}_{2}$ in the oxygenator varied between 150 and $450 \mathrm{mmHg}$.

In group II experiments (Fig. 1) three anaesthetized, apnoeic puppies weighing $3-4 \mathrm{~kg}$ were placed on scales and served as test animals. Anaesthetized support animals weighing $30 \mathrm{~kg}$ were placed $1 \mathrm{~m}$ below the puppies. A No. 14 USCI venous drainage cannula was inserted into the right atrium through the jugular vein of the puppy and was then connected by Tygon tubing to a similar cannula inserted into the jugular vein of the support animal. Oxygenated blood, from a No. 16 Bardic cannula inserted in the femoral artery of the support dog, was pumped (by the support dog) into the jugular vein of the puppy. All tubing was coated with graphite benzalkonium and heparin. Flow was monitored by a flow probe placed around one connecting line and adjusted by thumb screw clamps placed on the arterial and venous lines so that the puppy's weight and vital signs remained constant.

Group III experiments (Fig. 2) consisted of three apnoeic test puppies and three adult support animals placed side by side. Venous blood was drawn from the right atrium of the puppy through a No. 14 USCI cannula inserted through the femoral vein. This blood 


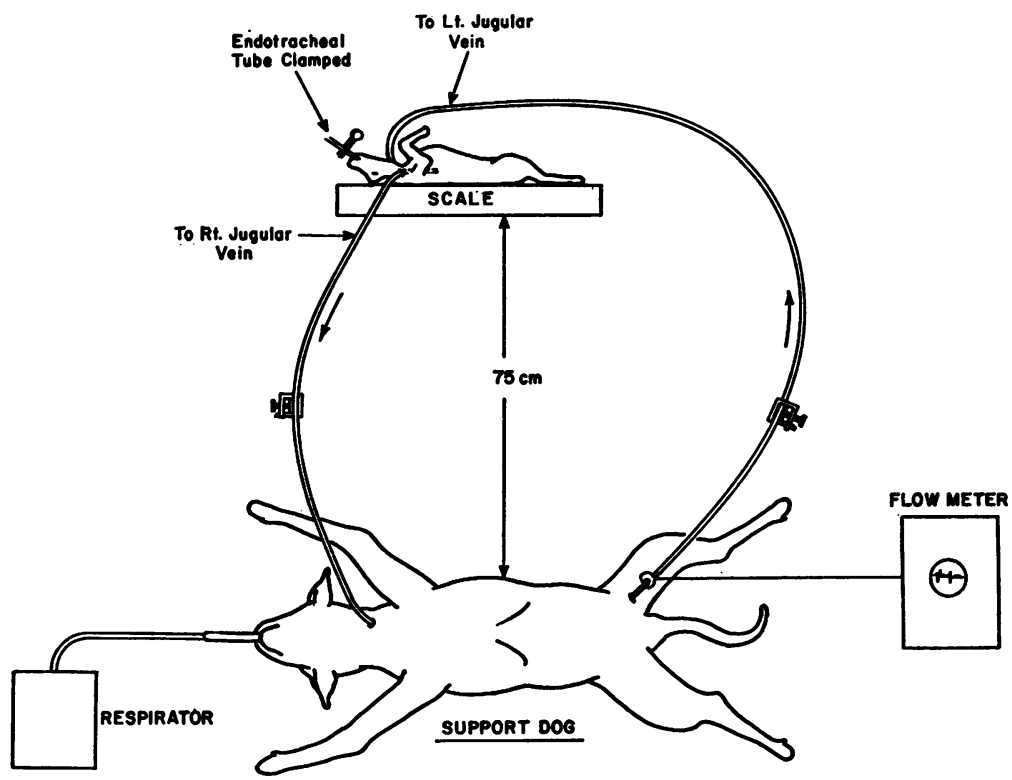

FIG. 1. Group II preparation with test animal above support animal. Venous drainage from test to support animals occurs by gravity while the support animal pumps arterial blood to the test animal.

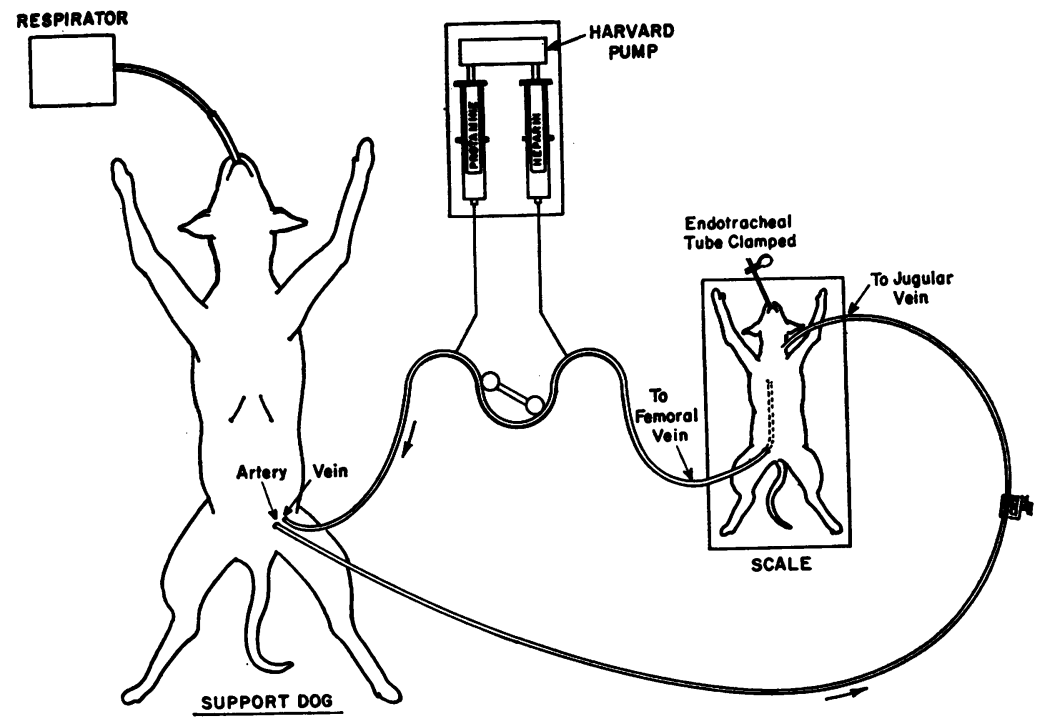

FIG. 2. Group III preparation with test and support animals side by side. Venous blood from the test animal is pumped into the support animal via a roller pump while the support animal pumps arterial blood to the test animal. 
was pumped by a Pemco microperfusion roller pump into the femoral vein of the support animal through a No. 14 Jelco needle. A similar No. 14 Jelco needle was inserted percutaneously into the support animal's femoral artery which then pumped arterial blood into the puppy through a No. 14 USCI cannula inserted in the jugular vein. All tubing again was coated with graphite benzalkonium and heparin except for that portion in the roller pump. Around that portion regional heparinization was used. This was controlled with a double syringe Harvard pump which gave a continuous infusion of $\mathbf{0 . 3}$ units of heparin per millilitre of blood flow per minute on the test animal side and an equal amount of protamine on the support animal side. Flow between the animals was regulated by the microprofusion pump and by adjusting a thumb screw clamp on the arterial cannula.

The support animals in all experiments were paralysed and ventilation-supported with a positive pressure apparatus to which a $30 \%$ oxygen mixture was added. The lungs of the test animals in groups II and III were expanded once each hour with positive pressure air to prevent atelectasis. Serial arterial blood gases of the test animals were recorded at 30 -minute intervals and the clotting times of both animals in the group III experiments were measured at hourly intervals.

\section{RESULTS}

In group $\mathrm{I}$, the most ideal $\mathrm{Po}_{2}$ of oxygenator blood was found to be $150 \mathrm{mmHg}$, there being negligible increased $\mathrm{Po}_{2}$ in the test animals with higher oxygenator values. The most satisfactory bypass ratio was $1: 1$, that is, venovenous bypass equal to the cardiac output. This provided an arterial $\mathbf{P O}_{2}$ in the test animal of $75 \mathrm{mmHg}$. Higher veno-
T A B LE I

DATA FROM GROUP I EXPERIMENTS

\begin{tabular}{|c|c|c|c|c|c|c|c|}
\hline \multicolumn{3}{|c|}{ Dog } & \multirow{2}{*}{$\begin{array}{c}\begin{array}{c}\text { Cardiac } \\
\text { Output } \\
\text { (ml/min) }\end{array} \\
2,000 \\
2,000 \\
2,000 \\
2,000\end{array}$} & \multirow{2}{*}{$\begin{array}{c}\begin{array}{c}\mathrm{Po}_{2} \text { in } \\
\text { Oxy- } \\
\text { genator }\end{array} \\
150 \\
150 \\
150 \\
150\end{array}$} & \multirow{2}{*}{$\begin{array}{c}\begin{array}{c}\text { Bypass } \\
\text { Flow } \\
\text { (ml/min) }\end{array} \\
650 \\
1,000 \\
2,000 \\
3,000\end{array}$} & \multirow{2}{*}{$\begin{array}{c}\begin{array}{c}\% \text { of } \\
\text { Cardiac } \\
\text { Output }\end{array} \\
30 \\
50 \\
100 \\
150\end{array}$} & \multirow{2}{*}{$\begin{array}{c}\begin{array}{c}\mathrm{Po}_{2} \text { of } \\
\mathrm{Dog}\end{array} \\
35 \\
40 \\
75 \\
88\end{array}$} \\
\hline 1 & $\cdots$ & $\cdots$ & & & & & \\
\hline 2 & $\cdots$ & $\cdots$ & $\begin{array}{l}1,800 \\
1,800 \\
1,800\end{array}$ & $\begin{array}{l}150 \\
150 \\
150\end{array}$ & $\begin{array}{r}600 \\
1,000 \\
1,800\end{array}$ & $\begin{array}{r}33 \\
55 \\
100\end{array}$ & $\begin{array}{l}38 \\
45 \\
78\end{array}$ \\
\hline 3 & . & $\cdots$ & $\begin{array}{l}2,100 \\
2,100 \\
2,100 \\
2,100\end{array}$ & $\begin{array}{l}150 \\
150 \\
150 \\
150\end{array}$ & $\begin{array}{r}700 \\
1,050 \\
2,100 \\
3,000\end{array}$ & $\begin{array}{r}33 \\
50 \\
100 \\
145\end{array}$ & $\begin{array}{l}32 \\
42 \\
70 \\
85\end{array}$ \\
\hline
\end{tabular}

venous bypass ratios did not increase arterial $\mathrm{Po}_{2}$ significantly while lower bypass ratios yielded an inadequate arterial $\mathrm{Po}_{2}$ (Table I). From these data it was concluded that satisfactory venovenous bypass could be performed provided the $\mathrm{Po}_{2}$ of venous infusion was $150 \mathrm{mmHg}$ and the bypass ratio was equal to the cardiac output of the animal to be supported.

In groups II and III, the calculated cardiac output of the puppies was approximately $300 \mathrm{ml} /$ min. In group II, the test animal maintained satisfactory blood gases (Table II) for 24 to 36 hours, at which time the experiments were electively terminated. In group III, the test animals maintained satisfactory blood gases (Table III) for 36 to 48 hours, at which time the experiments were also electively terminated. Clotting times remained normal in all group III experiments.

T A B LE I I

DATA FROM GROUP II EXPERIMENTS

\begin{tabular}{|c|c|c|c|c|c|c|c|c|c|c|c|c|}
\hline \multirow{2}{*}{ Puppy } & \multirow{2}{*}{$\begin{array}{c}\mathrm{PO}_{2} \\
\text { Support } \\
\text { Dog } \\
(\mathrm{mmHg})\end{array}$} & \multirow{2}{*}{$\begin{array}{l}\text { Weight } \\
\text { of } \\
\text { Puppy } \\
\text { (kg) }\end{array}$} & \multirow{2}{*}{$\begin{array}{l}\text { Weight } \\
\text { of } \\
\text { Support } \\
\text { Dog (kg) }\end{array}$} & \multirow{2}{*}{$\begin{array}{l}\text { Cross } \\
\text { Circula- } \\
\text { tion } \\
(\mathrm{ml} / \mathrm{min})\end{array}$} & \multicolumn{2}{|c|}{$\begin{array}{l}\mathrm{Po}_{2} \text { of Puppy } \\
\text { (mmHg) }\end{array}$} & \multicolumn{2}{|c|}{$\mathrm{PCO}_{2}$} & \multicolumn{2}{|c|}{$\mathrm{pH}^{+}$} & \multirow{2}{*}{$\begin{array}{c}\text { Haemolysis } \\
\text { at } \\
\text { Sacrifice } \\
\text { (mg \%) }\end{array}$} & \multirow{2}{*}{$\begin{array}{c}\text { Survival } \\
\text { (Sacri- } \\
\text { fice) } \\
\text { (hr) }\end{array}$} \\
\hline & & & & & Max. & Min. & Max. & Min. & Max. & Min. & & \\
\hline $\begin{array}{l}\mathbf{1} \\
\mathbf{2} \\
\mathbf{3}\end{array}$ & $\begin{array}{l}175 \\
135 \\
150\end{array}$ & $\begin{array}{l}3 \\
3 \\
3\end{array}$ & $\begin{array}{l}25 \\
28 \\
24\end{array}$ & $\begin{array}{l}300 \\
300 \\
400\end{array}$ & $\begin{array}{l}78 \\
75 \\
79\end{array}$ & $\begin{array}{l}44 \\
52 \\
49\end{array}$ & $\begin{array}{l}44 \\
48 \\
40\end{array}$ & $\begin{array}{l}32 \\
28 \\
29\end{array}$ & $\begin{array}{l}7 \cdot 32 \\
7 \cdot 39 \\
7 \cdot 29\end{array}$ & $\begin{array}{l}7 \cdot 44 \\
7 \cdot 45 \\
7 \cdot 51\end{array}$ & $\begin{array}{l}4 \\
4 \\
5\end{array}$ & $\begin{array}{l}24 \\
24 \\
36\end{array}$ \\
\hline
\end{tabular}

T A B LE I I I

DATA FROM GROUP III EXPERIMENTS

\begin{tabular}{|c|c|c|c|c|c|c|c|c|c|c|c|c|}
\hline \multirow{2}{*}{ Puppy } & \multirow{2}{*}{$\begin{array}{c}\mathbf{P o}_{\mathbf{g}} \\
\text { Support } \\
\text { Dog } \\
(\mathrm{mmHg})\end{array}$} & \multirow{2}{*}{$\begin{array}{l}\text { Weight } \\
\text { of } \\
\text { Puppy } \\
\text { (kg) }\end{array}$} & \multirow{2}{*}{$\begin{array}{c}\text { Weight } \\
\text { of } \\
\text { Support } \\
\text { Dog (kg) }\end{array}$} & \multirow{2}{*}{$\begin{array}{c}\text { Cross } \\
\text { Circula- } \\
\text { tion } \\
(\mathrm{ml} / \mathrm{min})\end{array}$} & \multicolumn{2}{|c|}{$\begin{array}{l}\mathrm{Po}_{2} \text { of Puppy } \\
(\mathrm{mmHg})\end{array}$} & \multicolumn{2}{|c|}{$\mathrm{PCO}_{2}$} & \multicolumn{2}{|c|}{$\mathrm{pH}^{+}$} & \multirow{2}{*}{$\begin{array}{c}\text { Haemolysis } \\
\text { at } \\
\text { Sacrifice } \\
(\mathrm{mg} \%)\end{array}$} & \multirow{2}{*}{$\begin{array}{c}\text { Survival } \\
\text { (Sacri- } \\
\text { fice) } \\
\text { (hr) }\end{array}$} \\
\hline & & & & & Max. & Min. & Max. & Min. & Max. & Min. & & \\
\hline $\begin{array}{l}1 \\
2 \\
3\end{array}$ & $\begin{array}{l}170 \\
155 \\
160\end{array}$ & $\begin{array}{l}3 \\
3 \cdot 5 \\
3 \cdot 8\end{array}$ & $\begin{array}{l}19 \\
24 \\
22\end{array}$ & $\begin{array}{l}300 \\
350 \\
400\end{array}$ & $\begin{array}{l}72 \\
78 \\
82\end{array}$ & $\begin{array}{l}50 \\
54 \\
58\end{array}$ & $\begin{array}{l}44 \\
42 \\
40\end{array}$ & $\begin{array}{l}29 \\
34 \\
36\end{array}$ & $\begin{array}{l}7 \cdot 32 \\
7 \cdot 30 \\
7 \cdot 28\end{array}$ & $\begin{array}{l}7 \cdot 44 \\
7 \cdot 46 \\
7 \cdot 39\end{array}$ & $\begin{array}{l}5 \\
6 \\
8\end{array}$ & $\begin{array}{l}48 \\
48 \\
36\end{array}$ \\
\hline
\end{tabular}




\section{DISCUSSION}

Although the method of pulmonary support in groups II and III was terminated at 24 to 48 hours, the true end point of the experiment, as determined by deteriorating blood gases, was never reached. The experiments in group II, despite maintenance of satisfactory blood gases of the test animal, presented certain difficulties which made running of the experiment difficult and would prevent their use clinically. These included the necessity for large femoral artery cannulae in the support dog, in order to reduce resistance so that the dog's own pumping mechanism could overcome gravity, and the necessity for large venous cannulae to insure adequate flow from the test to the support animal. In addition, it was difficult to regulate the flow between the two animals and constant watching and fine adjustment were required. By contrast, the group III experiments, with both animals at the same level, were quite easy to control. The greatest advantage, however, was that small cannulae could be used in both the support and test animals. This allowed a simple preparation in which dissection of the support animal's femoral vessels and the test animal's jugular and femoral vessels could be minimized.

The greatest problem with this type of pulmonary support is that the volume of blood trans- ferred between the test and support animals must be equal to the cardiac output of the test animal. This is higher than has previously been reported (Zotti et al., 1966) but may be accounted for in that previous studies did not use totally apnoeic test animals. Because of this, support of larger animals might have been difficult due to the excessive cardiac load which the support animal would be required to bear. However, when the size differential was large, as between puppy and adult dog, oxygenation of the puppy was adequate and the support animal could easily handle the increased cardiac output.

Regarding clinical application, these data indicate that an infant with hyaline membrane disease, for example, could be supported for a period of several days, the supporting individual being a parent or relative of similar blood type in whom a Scribner shunt, similar to the renal dialysis situation, had been inserted.

\section{REFERENCES}

White, J. J., Andrews, H. G., Risemberg, H., Mazur, D. and Haller, J. A. (1971). Prolonged respiratory support in newborn infants with a membrane oxygenator. Surgery, 70, 288.

Zotti, E. F., Ikeda, S., Lesage, A. M., Sealy, W. C., and Young, W. G. (1966). Prolonged veno-venous perfusion with a membrane oxygenator for respiratory failure. Journal of Thoracic and Cardiovascular Surgery, 51, 383. 